Article

\title{
Coping with Climate Change among Adolescents: Implications for Subjective Well-Being and Environmental Engagement
}

\author{
Maria Ojala \\ Department of Education, Uppsala University, Box 2136, 75002 Uppsala, Sweden; \\ E-Mail: maria.ojala@edu.uu.se; Tel.: +46-19-4712422
}

Received: 13 March 2013; in revised form: 26 April 2013 / Accepted: 12 May 2013 /

Published: 14 May 2013

\begin{abstract}
The objective of this questionnaire study was to investigate how Swedish adolescents $(n=321)$ cope with climate change and how different coping strategies are associated with environmental efficacy, pro-environmental behavior, and subjective well-being. The results were compared to an earlier study on 12-year-olds, and the same coping strategies, problem-focused coping, de-emphasizing the seriousness of the threat, and meaning-focused coping, were identified. As in the study on children, problem-focused and meaning-focused coping were positively related to felt efficacy and environmental behavior, while de-emphasizing the threat was negatively related to these measures. As expected, the more problem-focused coping the adolescents used, the more likely it was that they experienced negative affect in everyday life. This association was explained by the tendency for highly problem-focused adolescents to worry more about climate change. In contrast, meaning-focused coping was positively related to both well-being and optimism. When controlling for well-known predictors such as values and gender, meaning-focused and problem-focused coping were independent positive predictors of environmental efficacy and pro-environmental behavior, while de-emphasizing the threat was a negative predictor of pro-environmental behavior. The results are discussed in relation to coping theories and earlier studies on coping with climate change.
\end{abstract}

Keywords: global climate change; problem-focused coping; meaning-focused coping; climate change skepticism; optimism; subjective well-being; negative affect; pro-environmental behavior; environmental efficacy 


\section{Introduction}

Researchers have recently begun arguing that global climate change is not only an environmental problem but also a socio-psychological problem, both in the sense that the western world's life-style to a large extent contributes to climate change and that the complexity and seriousness of this problem could turn it into a psychological stressor [1-3]. How people psychologically cope with climate change could be related both to environmental engagement and well-being [2,4-7]. There are, however, few empirical studies that have focused on this topic, and those that exist were mainly conducted with adults $[5,8]$. Since young people are the future politicians, business leaders, and scientists, it is important to find out how this group handles climate change at a psychological level. The aim of this study was therefore to explore how a group of Swedish late adolescents cope with global climate change and how these coping strategies relate to subjective well-being (positive affect, negative affect, life satisfaction) and environmental engagement (environmental efficacy, pro-environmental behavior).

In the remainder of this introductory section, coping is first defined. Thereafter, some studies on climate change and coping are introduced. Finally, the more specific aims of the study are presented.

\subsection{The Concept of Coping}

Coping is about humans trying to handle diverse kinds of psychological threats and stressors; it concerns: "cognitive and/or behavioral efforts to manage specific external and/or internal demands" ([9], p. 141). Research in this area has often focused on stressors and negative emotions in a proximal context, for example, interpersonal worry. However, according to Lazarus and Folkman [9], the creators of one of the most well-known theories about coping, societal problems and related feelings such as powerlessness can also be defined as stressors. In addition, coping is not only about dealing with threats to one's own well-being, but also concerns perceived threats to the well-being of others. In the case of climate change these "others" could be future generations, animals, and people living in different parts of the world [10,11]. It is important to learn how to constructively cope with other-oriented worries; otherwise they could turn into self-focused worry and result in passivity instead of pro-social/pro-environmental engagement [12,13].

In Lazarus and Folkman's [9] coping theory, two main ways of coping are distinguished: problem-focused and emotion-focused coping. When using problem-focused coping, people confront the problem/stressor; they search, for instance, for information about what they themselves can do to solve the problem or they talk with others to get information about what one can do. Problem-focused coping is seen as an adaptive way of dealing with stress, and studies have shown that these strategies often are positively related to well-being $[9,14]$. However, it has also been found that when stressors are more or less uncontrollable, for instance when the stressor is a societal threat, problem-focused coping can sometimes create more distress and, thus, be associated with low well-being [15-17].

When using emotion-focused coping, people are not primarily trying to do something about the problem causing the stress; instead they use different strategies to soothe or get rid of the negative emotions [9]. Strategies such as distancing oneself from the emotions, or avoiding or denying the stressor are utilized. Just as in the case of problem-focused coping, the relations between emotion-focused strategies and measures of well-being are mixed and context-dependent. When 
stressors are uncontrollable, these strategies can be necessary and beneficial [18], however, when used too frequently in a micro context they can adversely affect well-being (for a review see [19]).

In recent years, the focus on how people regulate negative emotions has been complemented with a third main way to cope: meaning-focused coping [20]. This includes strategies such as positive re-appraisal (acknowledging the stressor but still being able to reverse one's perspective), finding meaning and benefits in a difficult situation, revising goals, and turning to spiritual beliefs. Meaning-focused coping has been found to be especially important when a stressor cannot be resolved at once, or perhaps not at all, such as when one has to care for a terminally ill partner. This way of coping is more closely related to the activation of positive emotions than the reduction of negative emotions. It is not equivalent to denial because positive emotions can instead help the person to confront a stressor and undertake problem-focused efforts, even when no immediate progress can be seen [20]. Positive emotions can also buffer against adverse physiological and psychological consequences of stress [21,22].

When it comes to coping among children and adolescents it has been found that they are less inclined to use problem-focused coping than adults [23]. This could be explained by the fact that young people do not have as much control over their actions as adults. They are for instance highly dependent upon how their parents act. Thus, it could be argued that for young people problem-focused coping could be more stressful, because even if they gain more information about what they can do about the stressor at hand, they may not be free to act because of their parents.

\subsection{Coping with the Climate Threat}

While research on how young people cope with negative emotions in relation to climate change is scarce, quite a few studies have explored young people's emotions concerning global problems such as climate change. These studies show that many young people, from middle childhood to late adolescence, experience negative emotions such as worry, sadness, anger, helplessness, and pessimism concerning these problems and the global future [24-33]. How young people cope with the emotions evoked is important to explore, since coping strategies could be even more important than the emotions themselves in influencing environmental engagement and well-being.

There is some research on adults about coping strategies in relation to the climate threat. Homburg and colleagues [5] performed a study where problem-focused strategies were found to be positively related to measures of both environmental stress and pro-environmental behavior. In addition, one emotion-focused strategy, denial of guilt, was negatively correlated with the same two measures. In an experimental study by van Zomeren and colleagues [8], people who used problem-focused coping in relation to the climate threat were more inclined to have environmental action intentions. Thus, these studies indicate that coping with the climate threat does have implications for well-being and environmental engagement.

Other studies have shown that it is quite common for adults to use distancing strategies to deal with the climate threat $[34,35]$. They, for instance, turn off the television when news about climate change is broadcasted. Although not as common, de-emphasizing the seriousness of the climate problem is also a strategy present in some groups. This could be a way to protect oneself against the anxiety evoked by the threat that climate change poses to deep-seated world-views, for instance conservatism 
or a belief in a just world [36,37]. Studies have also found that children as young as eleven years of age sometimes use these denial-like strategies to deal with climate change $[11,17,38]$.

A qualitative study investigating how children, adolescents, and young adults cope with climate change revealed that in addition to problem-focused and emotion-focused coping, meaning-focused strategies were quite often used to activate hope in relation to climate change [11]. More specifically young people's meaning-focused strategies included both positive reappraisal, i.e., acknowledging that the climate threat is a big problem but also perceiving hopeful aspects such as increased knowledge about this threat in society, and trust, i.e., being able to remind oneself in times of stress that one has trust in different societal actors. Thus, these strategies were similar to meaning-focused coping strategies as used in other coping domains (positive re-appraisal and spiritual beliefs/trust) and they were used more to activate positive emotions than to get rid of negative emotions (see [20]).

In a study on a group of 12-year-olds, the coping strategies identified in the qualitative study described above were transformed into quantitative measures. A principal component analysis was performed and three reliable coping strategies were identified: problem-focused coping (cognitive), de-emphasizing the seriousness of climate change (denial, egocentric thinking, not caring), and meaning-focused coping (positive reappraisal, trust). Thereafter, the study explored the relationships between these strategies used to cope with the climate threat, on the one hand, and environmental engagement and subjective well-being, on the other hand [17]. One hypothesis was that because climate change is a more or less uncontrollable stressor, something that an individual hardly can cope with alone, problem-focused coping could be associated with low well-being. This might be even more true for children who are dependent on their parents and cannot do whatever they want when it comes to living in an environmentally friendly fashion. Since meaning-focused coping has been found to be beneficial in connection with stressors in a proximal context that cannot be solved immediately, another hypothesis was that this strategy would also be constructive when coping with climate change, i.e., that it would be positively related to both well-being and environmental engagement. For instance, having trust in other actors when it comes to improving the climate problem seems necessary for wellbeing but also for environmental engagement, because it is hard to feel that one's own actions are effective if one does not have faith that other more powerful actors will do their part.

The more specific results of the study were that de-emphasizing the threat, a kind of emotion-focused coping, had negative relations to both felt environmental efficacy and pro-environmental behavior, while problem-focused and meaning-focused coping had positive associations with the same measures [17]. However, problem-focused coping also had a positive relation to general negative affect, i.e., to depressive and anxious feelings in everyday life. This association was explained by the fact that highly problem-focused children worried a lot about climate change. No relations were identified between problem-focused coping and the other facets of subjective well-being: life satisfaction and general positive affect. In contrast, the more meaning-focused coping the children employed, the more likely it was that they felt a high degree of general positive affect and life-satisfaction, and the less likely it was that they felt general negative affect. Furthermore, meaning-focused coping, optimism concerning climate change, and a high degree of purpose in life served as buffers against general negative affect for children who scored high on problem-focused coping. In sum, the results of this study indicate that cognitive problem-focused coping is associated in 
this age-group with general negative affect. The study also shows the benefits related to the use of meaning-focused coping and this coping strategy's close association with positive emotions.

\subsection{Aims of the Study}

In the study on 12-year-olds described above, the need to conduct similar studies on other age-groups of young people was pointed out [17]. For instance, adolescents are more cognitively mature than children and also have gained some freedom from their parents despite still living at home. Therefore, perhaps the relation between problem-focused coping and well-being is different in this group. On the other hand, adolescents are probably better able to grasp the complexity of the climate problem, and therefore even constructive coping strategies may not be able to counteract the negative emotions that are evoked by this increased knowledge (see also [11]). Thus, the goal of the present study was to investigate the following questions: (1) whether the same three coping strategies that were found among the children can be identified in a group of late adolescents; (2) if so, whether these strategies relate in the same way to measures of environmental engagement and measures of subjective well-being; (3) under the condition that problem-focused coping has a positive relation to general negative affect, whether this could be explained by a high degree of worry about climate change, as was the case in the study on the 12-year-olds; (4) whether meaning-focused coping and optimism concerning climate change serve as buffers against negative affect among the problem-focused adolescents, as they did in the study on 12-year-olds. An additional aim was to use regression analyses to examine (5) whether the three coping strategies have significant impacts on felt environmental efficacy and pro-environmental behavior when controlling for already well-known predictors of environmental engagement such as gender [39,40], perceived knowledge [39-44], environmental values $[39,45,46]$, and social influence from/communication with parents and peers [39,47]. These are all factors that in numerous studies have been found to be important in explaining environmental engagement. A more thorough review of their importance is, however, beyond the scope of this paper [48].

\section{Method}

\subsection{Procedure and Participants}

The study took place during the winter/spring 2010 among senior high-school students living in five municipalities in central Sweden. The study was conducted during regular school hours in the classroom. Teachers were not present and the questionnaire was administered by trained test leaders. The participants were ensured anonymity.

The sample consisted of 321 participants, 167 girls (52\%) and 150 boys (47\%) [49]. Their average age was 17.2 years $(\mathrm{SD}=0.49)$. In order to attain a representative distribution with respect to socioeconomic factors, both college preparatory and vocational classes were included in the study. The participation rate was $84 \%$.

\subsection{Measures [50,51]}

The questionnaire contained: questions about age and gender; four questions about environmental efficacy (two captured individual self-efficacy and two captured collective efficacy); twelve items 
about pro-environmental behavior (behavior in everyday life and communicating the need to do something); five items regarding worry about climate change (negative consequences for themselves, their close ones, future generations, people living in economically deprived countries, animals and nature); three questions about optimism concerning climate change (see [17] for more information about these measures). Sample items and Cronbach's alphas for these scales are presented in Table 1.

Different dimensions of subjective well-being [52,53] were captured with: a Swedish translation of a seven-item scale aiming to assess young people's thoughts about their own lives, i.e., life satisfaction [54]; a measure containing seven items about anxious and depressive feelings felt during the last week, i.e., general negative affect [55]; and finally a three-item measure about general positive affect [55]. Sample items and Cronbach's alphas for these scales are presented in Table 1.

Table 1. Typical items and Cronbach's alpha of scales included in the study.

\begin{tabular}{|c|c|c|c|}
\hline Scale & $\begin{array}{l}\text { Number } \\
\text { of items }\end{array}$ & Typical items & $\begin{array}{c}\text { Cronbach's } \\
\text { alpha }\end{array}$ \\
\hline $\begin{array}{l}\text { Worry about climate } \\
\text { change [17] }\end{array}$ & 5 & $\begin{array}{l}\text { self, relatives, future generations, animals/ nature, } \\
\text { people in economically deprived countries }\end{array}$ & 0.90 \\
\hline $\begin{array}{l}\text { Pro-environmental } \\
\text { behavior [17] }\end{array}$ & 12 & $\begin{array}{l}\text { Bicycle to school } \\
\text { Try to influence my parents }\end{array}$ & 0.87 \\
\hline Communication peers [39] & 2 & $\begin{array}{l}\text { Do your friends try to encourage you to become more } \\
\text { aware of environmental issues? }\end{array}$ & 0.78 \\
\hline Communication parents [39] & 2 & $\begin{array}{l}\text { Have your parents tried to make you do more for the } \\
\text { environment (recycling, saving energy, and so on)? }\end{array}$ & 0.85 \\
\hline $\begin{array}{l}\text { Optimism-climate } \\
\text { change [17] }\end{array}$ & 3 & $\begin{array}{l}\text { I think the climate problem will be solved in the future } \\
\text { I believe the future looks bright when it comes to } \\
\text { climate change }\end{array}$ & 0.81 \\
\hline $\begin{array}{l}\text { General negative } \\
\text { affect [55] }\end{array}$ & 7 & $\begin{array}{l}\text { I have worried about things I don't usually worry } \\
\text { about } \\
\text { I have felt down and unhappy }\end{array}$ & 0.90 \\
\hline General positive affect [55] & 3 & $\begin{array}{l}\text { During the last week I have felt happy } \\
\text { During the last week I have laughed }\end{array}$ & 0.78 \\
\hline Environmental values [39] & 4 & $\begin{array}{l}\text { I strongly believe that people should care for the } \\
\text { environment } \\
\text { It is important for me to adapt to and to fit into nature }\end{array}$ & 0.89 \\
\hline Life-satisfaction [54] & 7 & $\begin{array}{l}\text { I have a good life } \\
\text { I wish I had a different kind of life (rev) }\end{array}$ & 0.88 \\
\hline Environmental efficacy [17] & 4 & $\begin{array}{l}\text { I can do something about climate change } \\
\text { We together can do something about climate change }\end{array}$ & 0.82 \\
\hline
\end{tabular}

Note: In the table the scales are presented in the same order as they were presented in the questionnaire. The coping scale, which is presented in the result section, was the second scale in the questionnaire, following the items about worry concerning climate change.

Also included were a four-item scale about environmental values, a two-item measure about environmental communication with parents, and a two-item measure concerning environmental communication with peers (see [39] for more information about these scales). In Table 1, sample items and Cronbach's alpha for these scales are displayed. Finally, one question about subjective knowledge 
was also included: "How much knowledge do you think you have about climate change, global warming?" The question was followed by four alternatives: "Practically none", "Rather little", "Quite a lot", "Very much".

\section{Results}

\subsection{Can the Three Coping Dimensions Be Replicated?}

The coping scale started with the following instruction: "When one hears about societal problems such as climate change, one can feel worried or upset. Below is a list and for every item we would like you to indicate how well it applies to what you do or think when you are reminded of climate change. Choose the alternative that you feel best applies to you, and choose only one alternative per item." The response alternatives were: "not true at all", "not very true", "fairly true", "very true", and "completely true". The list included statements capturing meaning-focused coping (trust and positive reappraisal), problem-focused coping (cognitive), and emotion-focused coping (de-emphasizing the seriousness of climate change) (see Table 2). The items were originally taken from a qualitative study in which young people wrote about how they cope with climate change [11], and therefore the items ought to have high face validity (see also [17]).

Table 2. The three factor solution of the coping scale with rotated factor loadings.

\begin{tabular}{|c|c|c|c|c|c|c|}
\hline \multicolumn{7}{|c|}{$\begin{array}{l}\text { Principal factor analysis } \\
\end{array}$} \\
\hline & \multicolumn{2}{|c|}{ Meaning-focused coping } & \multicolumn{2}{|c|}{ De-emphasizing /don't care } & \multicolumn{2}{|c|}{ Problem-focused coping } \\
\hline & $\begin{array}{l}\text { More and more } \\
\text { people have started to } \\
\text { take climate change } \\
\text { seriously }\end{array}$ & 0.54 & $\begin{array}{l}\text { I think that the } \\
\text { problem is } \\
\text { exaggerated }\end{array}$ & 0.61 & $\begin{array}{l}\text { I think about what } \\
\text { I myself can do }\end{array}$ & 0.63 \\
\hline & $\begin{array}{l}\text { I have faith in } \\
\text { humanity; we can fix } \\
\text { all problems }\end{array}$ & 0.58 & $\begin{array}{l}\text { I don't care since I } \\
\text { don't know much } \\
\text { about climate change }\end{array}$ & 0.47 & $\begin{array}{l}\text { I search for } \\
\text { information about } \\
\text { what I can do }\end{array}$ & 0.62 \\
\hline & $\begin{array}{l}\text { I trust scientists to } \\
\text { come up with a } \\
\text { solution in the future }\end{array}$ & 0.54 & $\begin{array}{l}\text { Climate change is } \\
\text { something positive } \\
\text { because the summers } \\
\text { will get warmer }\end{array}$ & 0.54 & $\begin{array}{l}\text { I talk with my } \\
\text { family and friends } \\
\text { about what one can } \\
\text { do to help }\end{array}$ & 0.69 \\
\hline & $\begin{array}{l}\text { I have faith in people } \\
\text { engaged in } \\
\text { environmental } \\
\text { organizations }\end{array}$ & 0.65 & $\begin{array}{l}\text { Nothing serious will } \\
\text { happen during my } \\
\text { lifetime }\end{array}$ & 0.60 & & \\
\hline & I trust the politicians & 0.56 & $\begin{array}{l}\text { Climate change does } \\
\text { not concern those of } \\
\text { us living in Sweden }\end{array}$ & 0.57 & & \\
\hline & $\begin{array}{l}\text { Even though it is a } \\
\text { big problem, one has } \\
\text { to have hope }\end{array}$ & 0.51 & & & & \\
\hline $\begin{array}{l}\text { Cronbach's } \\
\text { alpha }\end{array}$ & & 0.74 & & 0.72 & & 0.75 \\
\hline
\end{tabular}

Note: Principal axis factoring was used as the extraction method, with Varimax rotation. 
A principal factor analysis using principal axis factoring as the extraction method and Varimax as the rotation method was conducted on the same 15 items that were included in the coping scale aimed at the children [17]. When the item "I can't be bothered to care about climate change" [56] was removed, using Kaiser's eigenvalue criterion, the remaining 14 items fell out in three separate subscales with acceptable Cronbach's alphas (see Table 2 for the items and alpha reliability). This factor solution accounted for $53 \%$ of the total variance and the factor loadings were satisfactory (see Table 2) [57]. Thus, the three coping scales, meaning-focused coping, problem-focused coping, and de-emphasizing the threat, identified in the study on 12-year-olds were also found in a late adolescents group.

The inter-correlations between the scales were: problem-focused coping-meaning focused coping, $\mathrm{r}=0.28(\mathrm{n}=320 ; p \leq 0.001) ;$ problem-focused coping-de-emphasizing the threat, $\mathrm{r}=-0.47$ ( $\mathrm{n}=320 ; p \leq 0.001)$; meaning-focused coping-de-emphasizing the threat, $\mathrm{r}=0.03(\mathrm{n}=320$; n.s.). Thus, the more the adolescents used problem-focused coping the more they were inclined to use meaning-focused coping and the less they de-emphasized the threat. In addition, there was no association between the use of meaning-focused coping and de-emphasizing the climate threat.

\subsection{How Do the Different Coping Strategies Relate to Engagement and Subjective Well-Being?}

In Table 3 the results of Pearson's correlation analyses between the three coping scales and measures of engagement and well-being are presented. As expected, problem-focused coping and meaning-focused coping had significant positive associations with environmental efficacy, and pro-environmental behavior. Worth noticing is that the correlation between problem-focused coping and pro-environmental behavior was much stronger than the correlation between meaning-focused coping and pro-environmental behavior. Furthermore, only meaning-focused coping had a positive relation to optimism concerning climate change. The finding that problem-focused coping did not have a significant relation to optimism is a result that differs from the study on the 12-year-olds. As expected, problem-focused coping was positively correlated with general negative affect, although the correlation was not particularly strong; that is, the more problem-focused coping the adolescents used, the more likely it was that they also experienced general negative affect in everyday life. Just as in the study on the children, there were no significant correlations with the other measures of subjective well-being (positive affect and life-satisfaction).

In the study on 12-year-olds, children who used a high degree of meaning-focused coping were less likely to experience negative affect; however, the present study failed to identify any significant relation between meaning-focused coping and negative affect (see Table 3). Still, the positive correlations between meaning-focused coping and life satisfaction, as well as general positive affect, were replicated. Just as in the study on 12-year-olds, while these correlations were not strong, they were still significant.

As expected, the emotion-focused strategy of de-emphasizing the seriousness of climate change was negatively related to environmental efficacy and pro-environmental behavior (see Table 3). However, the results differed from the study on 12-year-olds in that this strategy did not have any significant relation to general negative affect, while a significant positive association with optimism was identified. 
Table 3. Pearson correlations between the three coping strategies and environmental engagement, worry, well-being, environmental values, subjective knowledge, and communication (parents, peers).

\begin{tabular}{cccc}
\hline & $\begin{array}{c}\text { Meaning-focused } \\
\text { coping }\end{array}$ & $\begin{array}{c}\text { De-emphasizing/ } \\
\text { don't care }\end{array}$ & $\begin{array}{c}\text { Problem-focused } \\
\text { coping }\end{array}$ \\
\hline Worry about climate change & $0.33 * * *(\mathrm{n}=320)$ & $-0.47 * * *(\mathrm{n}=320)$ & $0.55 * * *(\mathrm{n}=320)$ \\
Optimism concerning & $0.54 * * *(\mathrm{n}=318)$ & $0.15 * *(\mathrm{n}=318)$ & $0.04(\mathrm{n}=318)$ \\
climate change & & $-0.36 * * *(\mathrm{n}=319)$ & $0.55 * * *(\mathrm{n}=319)$ \\
Environmental efficacy & $0.42 * * *(\mathrm{n}=319)$ & $-0.49 * * *(\mathrm{n}=320)$ & $0.68 * * *(\mathrm{n}=320)$ \\
Pro-environmental behavior & $0.30 * * *(\mathrm{n}=320)$ & $-0.09(\mathrm{n}=319)$ & $0.18 * * *(\mathrm{n}=319)$ \\
General negative affect & $-0.00(\mathrm{n}=319)$ & $0.05(\mathrm{n}=319)$ & $-0.06(\mathrm{n}=319)$ \\
General positive affect & $0.20 * * *(\mathrm{n}=319)$ & $0.02(\mathrm{n}=318)$ & $-0.04(\mathrm{n}=318)$ \\
Life satisfaction & $0.18 * * *(\mathrm{n}=318)$ & $-0.49 * * *(\mathrm{n}=316)$ & $0.58 * * *(\mathrm{n}=316)$ \\
Environmental Values & $0.31 * * *(\mathrm{n}=316)$ & $-0.24 * * *(\mathrm{n}=319)$ & $0.29 * * *(\mathrm{n}=319)$ \\
Communication parents & $0.23 * * *(\mathrm{n}=319)$ & $-0.15 * *(\mathrm{n}=320)$ & $0.34 * * *(\mathrm{n}=320)$ \\
Communication peers & $0.20 * * *(\mathrm{n}=320)$ & $-0.33 * * *(\mathrm{n}=319)$ & $0.30 * * *(\mathrm{n}=319)$ \\
Subjective knowledge & $0.05(\mathrm{n}=319)$ &
\end{tabular}

Note: $* p \leq 0.05 ; * * p \leq 0.01 ; * * * p \leq 0.001$.

In contrast to the study on children, in the present study the correlations between the three coping strategies, on the one hand, and environmental values, communication about environmental issues with parents and peers, and subjective knowledge, on the other hand, were also explored. In Table 3 one can see that problem-focused coping was positively related to all these four measures, and the same was true for meaning-focused coping, except that there was no significant correlation with subjective knowledge. Thus, the use of meaning-focused coping says nothing about a person's level of knowledge about climate change. Finally, it is interesting to note that de-emphasizing the seriousness of climate change was significantly negatively associated with environmental values and communication with parents and peers, as well as with subjective knowledge (see Table 3 ).

\subsection{Is Problem-Focused Coping Associated with General Negative Affect Because These Strategies} Make Adolescents More Worried about Climate Change?

As was the case in the study on 12-year-olds, the first step was to correlate problem-focused coping with worry about climate change (see [17]). A significant positive association was identified, with $\mathrm{r}=0.55(\mathrm{n}=320 ; p \leq 0.001)$. Thereafter, a partial correlation analysis [58] was performed between problem-focused coping and general negative affect, with worry as a control variable. When controlling for worry, the relation between problem-focused coping and negative affect was no longer significant, with $r=0.03(n=316$; n.s.). Thus, it seems as if a higher degree of worry about climate change can explain the association between problem-focused coping and general negative affect, which is in accordance with the results in the study on 12-year-olds. 


\subsection{Do Meaning-Focused Coping and Optimism Concerning Climate Change Buffer against A High} Degree of General Negative Affect for Adolescents with High Scores for Problem-Focused Coping?

Two hierarchical regression analyses were conducted in order to predict negative affect. In one, problem-focused coping, meaning-focused coping, and their interaction term were included as independent variables. In the other, problem-focused coping, optimism, and their interaction term were included as independent variables. In contrast to the study on 12-year-olds, neither meaning-focused coping nor optimism buffered against negative affect among highly problem-focused young people; i.e., the two interaction effects were not significant.

\subsection{Predicting Environmental Efficacy}

A hierarchical multiple regression analysis was performed in order to discern if the three coping strategies had significant impacts on felt environmental efficacy even when controlling for some already well-known predictors of environmental engagement. As can be seen in Table 4, taken alone, gender was a significant negative predictor; girls were more likely to feel efficacious concerning the environment than boys. However, this gender effect disappeared when the other control variables were included in the model in step two. In step three, the coping strategies were inserted and they together explained an additional eight percent of the variance in environmental efficacy (see Table 4). Both problem-focused coping and meaning-focused coping contributed independently and positively to explaining felt environmental efficacy. Meaning-focused coping was the stronger of these two predictors, and the second strongest of all the factors in the model. In contrast, de-emphasizing the climate threat was not a significant predictor when controlling for the other factors. In addition, environmental values and subjective knowledge were also unique significant positive predictors of environmental efficacy, while environmental communication with peers was a significant negative predictor. Environmental values turned out to be the most important explanatory factor in the final model. The proportion of variance accounted for by the full model was $52 \%, \mathrm{~F}(8,310)=40.19$; $p<0.001$.

Table 4. Hierarchical multiple regression models predicting environmental efficacy.

\begin{tabular}{lccc}
\hline & \multicolumn{3}{c}{ Environmental efficacy } \\
\cline { 2 - 4 } & Step 1 & Step 2 & Step 3 \\
& $\beta$ & $\beta$ & $\beta$ \\
\hline Gender (girls = 0; boys $=1)$ & $-0.22 * * *$ & -0.09 & -0.05 \\
Environmental values & & $0.56 * * *$ & $0.39 * * *$ \\
Communication parents & & 0.05 & 0.00 \\
Communication peers & & -0.02 & $-0.10^{*}$ \\
Subjective knowledge & & $0.16 * * *$ & $0.13 * *$ \\
Meaning-focused coping & & & $0.24 * * *$ \\
De-emphasizing the threat & & & -0.05 \\
Problem-focused coping & & & $0.22 * * *$ \\
$\mathbf{R}^{2}$ & $\mathbf{0 . 0 5} * * *$ & $\mathbf{0 . 4 3} * * *$ & $\mathbf{0 . 5 2} * * *$ \\
Adjusted $\mathbf{R}^{2}$ & $\mathbf{0 . 0 4} * * *$ & $\mathbf{0 . 4 2} * * *$ & $\mathbf{0 . 5 0} * * *$ \\
$\Delta \mathbf{R}$ & & $\mathbf{0 . 3 9} * * *$ & $\mathbf{0 . 0 8} * * *$ \\
\hline
\end{tabular}

Note: $* p \leq 0.05 ; * * p \leq 0.01 ; * * * p \leq 0.001$. 


\subsection{Predicting Pro-Environmental Behavior}

In order to discover any possible independent contributions of the three coping strategies in explaining pro-environmental behavior, a second hierarchical multiple regression analysis was performed. In this case, gender was an important predictor, both alone and when the other control variables and two of the coping strategies were held constant in steps two and three (see Table 4). The girls were more inclined to behave pro-environmentally than the boys. However, gender did not significantly predict pro-environmental behavior in the final step, when the all coping strategies were included.

Because problem-focused coping is quite close to the measure of pro-environmental behavior and because it is inter-correlated with both meaning-focused coping and de-emphasizing the threat, in the third step only meaning-focused coping and de-emphasizing the threat were entered. As shown in Table 4, these two coping strategies were independent predictors of pro-environmental behavior, with meaning-focused coping being a positive predictor, and de-emphasizing being a negative predictor. Finally, in the fourth step, problem-focused coping was entered and was found to be an independent significant positive predictor, in this case the most potent explanatory factor. Meaning-focused coping lost its significance when problem-focused coping was entered into the model, while de-emphasizing remained a significant negative predictor. Together, the three coping strategies contributed an additional 10 percent of the variance in pro-environmental behavior (see Table 5). Furthermore, subjective knowledge, environmental communication with both peers and parents, and environmental values were significant predictors in the fourth step, and in all these cases the relations were positive. The final model accounted for 61 percent of the variance, $\mathrm{F}(8,310)=58.10 ; p<0.001$.

Table 5. Hierarchical multiple regression models predicting reported pro-environmental behavior.

\begin{tabular}{l|c|c|c|c}
\hline & \multicolumn{4}{|c}{ Pro-environmental behavior } \\
\hline & Step 1 & Step 2 & Step 3 & Step 4 \\
& $\beta$ & $\beta$ & $\beta$ & $\beta$ \\
\hline Gender (girls =0; boys =1) & $-0.22 * * *$ & $-0.09 *$ & $-0.09 *$ & -0.05 \\
\hline Environmental values & & $0.46 * * *$ & $0.35 * * *$ & $0.24 * * *$ \\
\hline Communication parents & & $0.15 * * *$ & $0.12 * *$ & $0.11 * *$ \\
\hline Communication peers & & $0.21 * * *$ & $0.20 * * *$ & $0.13 * * *$ \\
\hline Subjective knowledge & & $0.18 * * *$ & $0.14 * * *$ & $0.10 *$ \\
\hline Meaning-focused coping & & & $0.11 * *$ & 0.07 \\
\hline De-emphasizing the threat & & & $-0.20 * * *$ & $-0.12 * *$ \\
\hline Problem-focused coping & & & & $0.35 * * *$ \\
\hline $\mathbf{R}^{2}$ & $\mathbf{0 . 0 5} * * *$ & $\mathbf{0 . 5 1} * * *$ & $\mathbf{0 . 5 4} * * *$ & $\mathbf{0 . 6 1} * * *$ \\
\hline Adjusted $\mathbf{R}^{2}$ & $\mathbf{0 . 0 5} * * *$ & $\mathbf{0 . 5 0} * * *$ & $\mathbf{0 . 5 3} * * *$ & $\mathbf{0 . 6 0} * * *$ \\
\hline$\Delta \mathbf{R}$ & & $\mathbf{0 . 4 6} * * *$ & $\mathbf{0 . 0 3} * * *$ & $\mathbf{0 . 0 7} * * *$ \\
\hline
\end{tabular}

Note: $* p \leq 0.05 ; * * p \leq 0.01 ; * * * p \leq 0.001$.

\section{Discussion}

In the present study the relations between how adolescents cope psychologically with climate change, on the one hand, and environmental engagement and measures of subjective well-being, on the 
other, were investigated. The results were compared with a previous study conducted with a group of 12-year-olds [17], and many of the most important results were replicated.

\subsection{Problem-Focused Coping}

The finding that late adolescents who think, talk, and search for information about what they personally can do when it comes to climate change, i.e. who use a high degree of problem-focused coping, also experience more general negative affect than those who do not, supports earlier studies indicating that the use of problem-focused coping in relation to, for the individual, more or less uncontrollable stressors such as societal problems is related to a high degree of stress [5,15-17]. Even though this coping strategy was also associated with a higher degree of environmental efficacy and more pro-environmental behavior, the search for information can make young people more worried about climate change, perhaps because the seriousness and complexity of this problem become more visible. For instance, media, a common source of information, often report in a paradoxical way about the apocalyptic nature of the climate problem at the same time as individuals' moral responsibility to do something about the problem is emphasized [34,59,60].

However, since this is only a correlation study, one cannot be certain that problem-focused coping evokes worry about climate change that, in turn, causes negative affect in general among the young. Even though there are some prior studies supporting the link between worry about global environmental problems and low well-being, they are all cross-sectional [61-63]. An alternative explanation could be that worry about climate change to some extent is a sub-type of a general tendency to experience anxious and depressive feelings in everyday life, as sometimes seems to be the case with nuclear worry (see [64,65]). If so, young people who experience a high degree of negative affect in general also worry more about climate change, and this worry then makes them search for information on what they can do about the problem, that is, makes them use more problem-focused coping. There are a large number of studies showing that worry focuses people's attention on the problem, which leads to a search for possible solutions (for a review, see [66]).

\subsection{Meaning-Focused Coping and Optimism}

This is the first study on adolescents, and the second study on young people including children, showing that those who use meaning-focused coping to a high degree feel more general positive affect, life-satisfaction, and optimism concerning climate change, and in addition behave more pro-environmentally and experience stronger feelings of environmental efficacy, than adolescents who use this coping strategy to a lesser degree. These results also support findings on coping in a proximal context showing the positive relations between meaning-focused coping and positive emotions as well as taking an active stance towards the stressor at hand [20,67].

A difference from the study on 12-year-olds was identified; meaning-focused coping did not have a significant negative relation to general negative affect [17]. This is not, however, a surprising result if one takes into account the original theory about this coping strategy. This theory emphasizes that meaning-focused strategies, first and foremost, are used to activate positive emotions, not to get rid of negative emotions, and that negative and positive affect are independent [20]. That a significant correlation was still identified among the 12-year-olds may be explained by the fact that positive and 
negative emotions tend not to be as independent among children as among adults, i.e., children to a higher degree perceive positive and negative emotions as opposite poles of one dimension and more seldom experience mixed emotions $[68,69]$. Thus, using meaning-focused coping to a high degree may perhaps be incompatible with feeling negative affect among children.

In contrast to the study on 12-year-olds [17], meaning-focused coping and optimism concerning climate change did not shield adolescents using a high degree of problem-focused coping from general negative affect. This could be due to some weaknesses with the design of this study, though it could also be a result that is specific to the age-group in focus. Since earlier studies indicate that late adolescents in general feel more helpless about global problems than children do, probably because they better understand the difficulty and complexity of these threats $[11,70,71]$, trusting different societal actors, being able to reverse one's perspective, and being optimistic are perhaps not enough to counteract the negative emotions related to problem-focused coping. Future studies should investigate whether there are other more general factors, such as a sense of meaning in life, which can protect against a high degree of negative affect among highly problem-focused adolescents.

Also of interest is that in this study optimism about climate change was more related to the use of de-emphasizing strategies than to problem-focused coping, with which no significant association was identified. This is in contrast to the study on 12-year-olds where children scoring high on optimism used more problem-focused coping, and where no relation to de-emphasizing the threat was found [17]. These diverging results could perhaps be explained by the fact that optimism is seen by some researchers as being closely related to wishful thinking [72]. While wishful thinking among children can be an age-appropriate way of dealing with threats, and therefore be related to pro-social behavior, among older persons it is rather a way to avoid taking on responsibility (see $[73,74]$ ). In relation to climate change Homburg and colleagues [5] found that wishful thinking among adults was negatively related to problem solving and positively related to denial of guilt. Furthermore, studies have shown that hope concerning climate change is a multifaceted concept; it can be based on both constructive meaning-focused strategies and denial-like coping (see [11,39]). In this regard it is worth noticing that in this study optimism was significantly positively related to both de-emphasizing the threat and meaning-focused coping, while these two coping strategies were not correlated with each other.

\subsection{Emotion-Focused Coping, De-emphasizing the Climate Threat}

Like the 12-year-olds, the adolescents who de-emphasized the seriousness of climate change, for instance by thinking that the climate problem is exaggerated, were less likely to feel a high degree of environmental efficacy and to behave pro-environmentally [17]. This result is also in accordance with at least one study on adults [5].

It is also interesting to note that adolescents who de-emphasized the climate threat scored lower on environmental values than those who did not deny the seriousness of the climate problem, which lends support to studies on adults showing that denial of, or skepticism concerning, climate change is closely related to specific world-views and values (see $[36,37,75,76]$ ). That de-emphasizing was significantly negatively related to subjective knowledge about climate change should, however, be interpreted cautiously, since one of the items included in this scale concerned not caring about climate change because one does not know enough about the problem. 


\subsection{Strengths, Limitations and Future Research}

Some strengths and limitations of this study should be noted. The main strength of this study is that it is the first that investigates the relations between coping with climate change and measures of both environmental engagement and subjective well-being among adolescents. As such it can provide valuable information to, for instance, teachers and parents who want to help young people to take on the climate challenge. The study also extends many of the results found in a similar study on 12-year-olds [17] and, thereby, takes important steps towards a more general picture of the implications of these coping strategies for environmental engagement and well-being. Nevertheless, there is still a need for more studies. For instance, do the results of the two studies performed only apply to Swedish young people or do children and adolescents in other countries cope the same way with climate change? If so, are the relations to engagement and well-being the same? Another weakness is that this study is crosssectional; experimental and longitudinal studies should be performed in order to find out more about the causal relations between the factors of interest.

Although exploring the relations between the three coping strategies and communication with parents and peers about environmental issues was not the main aim of this study, it is still interesting to note that adolescents who used meaning-focused and problem-focused coping to deal with the climate problem also communicated more about environmental issues with their parents and peers. Those who utilized de-emphasizing as a coping strategy instead talked less with their parents and peers about environmental issues. These results are in accordance with prior research showing the significance of discussions with parents and friends for emotion regulation and coping at an individual level among young people (for a review see [77]). These previous studies have, however, only focused upon emotion regulation in a proximal context, and therefore the results of the present study are the first to indicate that communication patterns about societal issues also could influence coping with societal threats. In future research it would be interesting to study in more detail which factors can explain the use of different coping strategies in relation to climate change among different groups of young people.

\subsection{Practical Implications}

The study has practical implications for education for sustainable development. Teachers need to take young people's emotions about climate change seriously and encourage them to verbalize them. In this way, different ways of coping with climate change can be discerned. In order to counteract the negative affect related to cognitive problem-focused strategies, teachers can help their pupils to find concrete actions concerning climate change and let them work together on these issues. Negative affect can be turned into something constructive when one feels some control over the problem [78]. Taking collective rather than individual action in the face of global environmental problems can also promote well-being [79].

Furthermore, to promote meaning-focused coping, teachers can help their pupils to challenge overly pessimistic views about climate change with realistic positive thinking [39]. They can also invite different societal actors, such as scientists and politicians, into the classroom. These could be people who work with issues related to climate change and who are optimistic despite the complexity of the problem. In this way trust can be promoted. Teachers should not, of course, promote blind trust. 
However, in order to avoid cynicism, it is important to show teenagers that some adults do care about these issues [80]. This is an important complement to critical thinking. Otherwise, feelings of helplessness and hopelessness can arise, which are not beneficial for an active approach to climate change.

In addition, because de-emphasizing the threat was related to less knowledge about climate change, more information about climate change could perhaps counteract this way of coping. However, teachers need to take care, because de-emphasizing also seems to be related to specific world-views, and studies have shown that concerning climate change, more scientific facts are only effective for those with egalitarian world-views [75]. Here, focusing on co-benefits of climate change actions, for instance scientific and economic progress, could be a constructive approach, since research has shown that it can motivate adult climate change skeptics to behave pro-environmentally [81]. The negative relation to environmental efficacy also suggests that trying to increase general self-efficacy among this group could be beneficial.

\section{Acknowledgments}

This study was supported by research grants to the author from the Swedish Research Council Formas.

\section{Conflict of Interest}

The author declares no conflict of interest.

\section{References and Notes}

1. Koger, S.M.; Leslie, K.E.; Hayes, E.D. Climate change: Psychological solutions and strategies for change. Ecopsychology 2011, 3, 227-235.

2. Reser, J.P.; Swim, J.K. Adapting to and coping with the threat and impacts of climate change. Am. Psychol. 2011, 66, 277-289.

3. Swim, J.; Clayton, S.; Doherty, T.; Gifford, R.; Howard, G.; Reser, J.; Stern, P.; Weber, E. Psychology and Global Climate Change: Addressing a Multi-faceted Phenomenon and Set of Challenges; American Psychological Association: Washington, DC, USA, 2009.

4. Homburg, A.; Stolberg, A. Explaining pro-environmental behavior with a cognitive theory of stress. J. Environ. Psychol. 2006, 26, 1-14.

5. Homburg, A.; Stolberg, A.; Wagner, U. Coping with global environmental problems: Development and first validation of scales. Environ. Behav. 2007, 39, 754-778.

6. Stokols, D.; Misra, S.; Runnerstrom, M.G.; Hipp, A.J. Psychology in an age of ecological crisis: From personal angst to collective action. Am. Psychol. 2009, 64, 181-193.

7. Swim, J.K.; Stern, P.C.; Doherty, T.J.; Clayton, S.; Reser, J.P.; Weber, E.U.; Gifford, R.; Howard, G.S. Psychology's contributions to understanding and addressing global climate change. Am. Psychol. 2011, 66, 241-250.

8. Van Zomeren, M.; Spears, R.; Leach, C.W. Experimental evidence for a dual pathway model analysis of coping with the climate crises. J. Environ. Psychol. 2010, 30, 339-346.

9. Lazarus, R.S.; Folkman, S. Stress, Appraisal, and Coping; Springer: New York, NY, USA, 1984. 
10. Ojala, M. Barns Känslor och Tankar om Klimatproblematiken; ER 2010:31; Energimyndigheten: Eskilstuna, Sweden, 2010.

11. Ojala, M. Regulating worry, promoting hope: How do children, adolescents, and young adults cope psychologically with climate change? Int. J. Environ. Sci. Educ. 2012, 7, 537-561.

12. Bengtsson, H. Children's cognitive appraisal of others' distressful and positive experiences. Int. J. Behav. Dev. 2003, 27, 457-466.

13. Eisenberg, N. Emotion, Regulation, and moral development. Annu. Rev. Psychol. 2000, 51, 665-697.

14. Clarke, A.T. Coping with interpersonal stress and psychosocial health among children and adolescents: A meta analysis. J. Youth Adolescence 2006, 35, 11-24.

15. Hallis, D.; Slone, M. Coping strategies and locus of control as mediating variables in the relation between exposure to political life events and psychological adjustment in Israeli children. Int. J. Stress Manage. 1999, 6, 105-123.

16. Heyman, J.C.; Brennan, M.; Colarossi, L. Event-exposure stress, coping, and psychological distress among New York students at six months after 9/11. Anxiety Stress Coping 2010, 23, 153-163.

17. Ojala, M. How do children cope with global climate change? Coping strategies, Engagement, and well-being. J. Environ. Psychol. 2012, 32, 225-233.

18. Landis, D.; Gaylord-Harden, N.K.; Malinowski, S.L.; Grant, K.E.; Carleton, R.A.; Ford, R.E. Urban adolescent stress and hopelessness. J. Adolescence 2007, 30, 1051-1070.

19. Frydenberg, E. Adolescent Coping: Advances in Theory, Research, and Practice; Routledge: New York, NY, USA, 2008; pp. 24-25.

20. Folkman, S. The case for positive emotions in the stress process. Anxiety Stress Coping 2008, 21, $3-14$.

21. Billings, D.W.; Folkman, S.; Acree, M.; Moskowitz, J.T. Coping and physical health during caregiving: The roles of positive and negative affect. J. Pers. Soc. Psychol. 2000, 79, 131-142.

22. Fredrickson, B.; Levenson, R. Positive emotions speed recovery from the cardiovascular sequel of negative emotions. Cognit. Emot. 1998, 12, 191-220.

23. Ryan-Wenger, N.M. A taxonomy of children's coping strategies. Am. J. Orthopsychiat. 1992, 62, 259-263.

24. Albert, M.; Hurrelmann, K.; Quenzel, G. Jugend 2010. Eine pragmatische Generation behauptet sich; Fischer Taschenbuch Verlag: Frankfurt am Main, Germany, 2010.

25. Connell, S.; Fien, J.; Lee, J.; Sykes, H.; Yencken, D. If it doesn't directly affect you, you don't think about it: A qualitative study of young people's environmental attitudes in two Australian cities. Environ. Educ. Res. 1999, 5, 95-113.

26. Dean, B. Pakistani children want a better future. Citizenship Teach. Learn. 2008, 4, 43-57.

27. Hicks, D.; Holden, C. Remembering the future: What do children think? Environ. Educ. Res. 2007, 13, 501-512.

28. Huh, H.-G. 'I hope Korea will be reunified again': Listening to Korean children. Citizenship Teach. Learn. 2008, 4, 18-30.

29. Naval, C.; Reparaz, C. Spanish children's concerns for the future. Citizenship Teach. Learn. 2008, 4, 31-42.

30. Strife, S.J. Children's environmental concerns: Expressing Ecophobia. J. Environ. Educ. 2012, $43,37-54$. 
31. Szagun, G.; Pavlov, V.I. Environmental Awareness: A Comparative Study of German and Russian Adolescents. Youth Soc. 1995, 27, 93-112.

32. Threadgold, S. 'I reckon my life will be easy, but my kids will be buggered': Ambivalence in young people's positive perceptions of individual futures and their visions of environmental collapse. J. Youth Stud. 2012, 5, 17-32.

33. Tucci, J.; Mitchell, J.; Goddard, C. Children's Fears, Hopes and Heroes: Modern Childhood in Australia; Australian Childhood Foundation: Melbourne, Australia, 2007.

34. Olausson, U. 'We're the Ones to Blame': Citizens' Representations of Climate Change and the Role of the Media. Environ. Commun. 2011, 5, 281-299.

35. Norgaard, K.M. 'People want to protect themselves a little bit': Emotions, Denial, and social movement nonparticipation. Sociol. Inq. 2006, 76, 372-396.

36. Feinberg, M.; Willer, R. Apocalypse soon? Dire messages reduce belief in global warming by contradicting just world beliefs. Psychol. Sci. 2011, 22, 34-38.

37. McCright, A.M.; Dunlap, R.E. Cole dudes: The denial of climate change among conservative white males in the United States. Global Environ. Chang. 2011, 21, 1163-1172.

38. Klöckner, C.A.; Beisenkamp, A.; Hallmann, S. Klimawandel aus der Sicht 9-14 jährige KinderEmotionen, Bewältigungressourcen und allgemeines Wohlbefinden. Umweltpsychology 2010, 14, 121-142.

39. Ojala, M. Hope and climate change: The importance of hope for pro-environmental engagement among young people. Environ. Educ. Res. 2012, 18, 625-642.

40. Zelezny, L.C.; Chua, P.P.; Aldrich, C. Elaborating on gender differences in environmentalism. J. Soc. Issues 2000, 56, 443-457.

41. Barr, S. What we buy, what we throw away and how we use our voice. Sustainable household waste management in the UK. Sustain. Dev. 2004, 12, 32-44.

42. Hornik, J.; Cherian, J. Determinants of recycling behavior: A synthesis of research results. J. SocioEcon. 1995, 24, 105-127.

43. Meinhold, J.L.; Malkus, A.J. Adolescent environmental behaviors: Can knowledge, attitudes, and self-efficacy make a difference? Environ. Behav. 2005, 37, 511-532.

44. Young, W.; Hwang, K.; McDonald, S.; Oates, S.J. Sustainable consumption: Green consumer behaviour when purchasing products. Sustain. Dev. 2010, 18, 20-31.

45. Pahl, S.; Harris, P.R.; Todd, H.A.; Rutter, D.R. Comparative optimism for environmental risks. J. Environ. Psychol. 2005, 25, 1-11.

46. Poortinga, W.; Steg, L.; Vlek, C. Values, environmental concern, and environmental behavior. A study into household energy use. Environ. Behav. 2004, 36, 70-93.

47. Grønhøj, A.; Thøgersen, J. Like father, like son? Intergenerational transmission of values, attitudes, and behaviours in the environmental domain. J. Environ. Psychol. 2009, 29, 414-421.

48. The reason for not performing regression analyses to predict the different dimensions of subjective well-being was that relevant well-known predictors of well-being that could work as control variables were unfortunately not included in the questionnaire.

49. Four persons did not answer the question about gender.

50. The coping scale is presented in the results section since one of the research questions concerns whether a three factor solution of the coping scale is possible to replicate in this study. 
51. At all times, the arithmetic mean of the items in the scales for each person was used to create aggregated measures.

52. Diener, E. Subjective well-being. Psychol. Bull. 1984, 96, 542-575.

53. Subjective well-being is said to consist of three dimensions: life-satisfaction, negative affect, and positive affect [53]. "Subjective" stands for the fact that the measures used are not objective, but try to capture how the person thinks and feels about his or her own life, i.e., that it is the person's own subjective evaluations that are of importance.

54. Huebner, E.S. Further validation of the Students' Life Satisfaction Scale: The independence of satisfaction and affect ratings. J. Psychoeduc Assess. 1991, 9, 363-368.

55. Radloff, L.S. The CES-D scale. A self-report depression scale of research in the general population. Appl. Psych. Meas. 1977, 1, 385-401.

56. In Swedish, this statement can imply a sense of helplessness rather than the more active way of denying that climate change is worth bothering about that we wanted to capture.

57. All but one factor had loading over 0.50 , and the exception, "I don't care since I don't know much about climate change" was close with a loading of 0.47 . Furthermore, there were not any substantial cross-loadings in this solution.

58. To answer this question a regression analysis can also be performed. However, because a partial correlation analysis was used in the study on 12-year-olds, the same approach was also chosen here in order to be able to compare the results.

59. Carvalho, A. Media(ted) discourses and climate change: A focus on political subjectivity and (dis)engagement. WIREs Clim. Change 2010, 1, 172-179.

60. Höijer, B. Emotional anchoring and objectification in the media reporting on climate change. Public Underst. Sci. 2009, 19, 717-731.

61. Antilla, T.; Poikolainen, K.; Uutela, A.; Lönnqvist, J. Structure and determinants of worrying among adolescent girls. J. Youth Stud. 2000, 3, 49-60.

62. Ojala, M. Adolescents' worries about environmental risks: Subjective well-being, Values, and existential dimensions. J. Youth Stud. 2005, 8, 331-348.

63. Searle, K.; Gow, K. Do concern about climate change lead to distress? Int. J. Clim. Change Strat. Manag. 2010, 2, 362-378.

64. Hamilton, S.B.; Keilin, W.G.; Knox, T.A.; Naginey, J.L. When thoughts turn toward nuclear war: Stress responses, coping strategies, and the importance of trait anxiety in moderating effects on "Mental health". J. Appl. Soc. Psychol. 1989, 19, 111-139.

65. Hollin, C.R. Concern about the threat of nuclear war: Just another worry? Anxiety Res. 1991, 4, 51-60.

66. Marcus, G.E. The Sentimental Citizen. Emotion in Democratic Politics; The Pennsylvania State University Press: University Park, PA, USA, 2002.

67. Stoeber, J.; Janssen, D.P. Perfectionism and coping with daily failures: Positive reframing helps achieve satisfaction at the end of the day. Anxiety Stress Coping 2011, 24, 477-497.

68. Larsen, J.T.; To, Y.M.; Fireman, G. Children's understandings and experience of mixed emotions. Psychol. Sci. 2007, 18, 186-191.

69. Pan, F.T.; Yu, L.S.; Zhang, Q. A review on the development of children's mixed emotions. Psychol. Sci. 2012, 35, 659-663. 
70. Eckersley, R. Dreams and expectations: Young people's expected and preferred futures and their significance for education. Futures 1999, 31, 73-90.

71. Hicks, D. A lesson for the future. Young people's hopes and fears for tomorrow. Futures 1996, 28, 1-13.

72. McGeer, V. The art of good hope. Ann. Am. Acad. Polit. Soc. Sci. 2004, 592, 100-127.

73. De Boo, G.M.; Wicherts, J.M. Assessing cognitive and behavioral coping strategies in children. Cognitive Ther. Res. 2009, 33, 1-20.

74. Miller, R.; Sabin, C.A.; Goldman, E.; Clemente, C.; Sadowski, H.; Taylor, B.; Lee, C.A. Coping styles in families with haemophilia. Psychol. Health Med. 2000, 5, 3-12.

75. Kahan, D.M.; Peters, E.; Wittlin, M.; Slovic, P.; Ouellette, L.L.; Braman, G.; Mandel, G. The polarizing impact of science literacy and numeracy on perceived climate change risks. Nature Clim. Change 2012, 2, 732-735.

76. Whitmarsh, L. Scepticism and uncertainty about climate change: Dimension, determinants and change over time. Global Environ. Change 2011, 21, 690-700.

77. Eisenberg, N.; Cumberland, A.; Spinrad, T.L. Parental Socialization of Emotion. Psychol. Inq. 1998, 4, 241-273.

78. MacGregor, D. Worry over technological activities and life concerns. Risk Anal. 1991 11, 315-324.

79. Ojala, M. Confronting macrosocial worries. Worry about environmental problems and proactive coping among a group of young volunteers. Futures 2007, 39, 729-745.

80. Colby, A.; Beaumont, E.; Ehrlich, T.; Corngold, J. Educating for Democracy; Jossey-Bass: San Fransisco, CA, USA, 2007; pp. 153-154.

81. Bain, P.G.; Hornsey, M.J.; Bongiorno, R.; Jeffries, C. Promoting pro-environmental action in climate change deniers. Nature Clim. Change 2012, 2, 600-603.

(C) 2013 by the author; licensee MDPI, Basel, Switzerland. This article is an open access article distributed under the terms and conditions of the Creative Commons Attribution license (http://creativecommons.org/licenses/by/3.0/). 